\title{
Cascading trophic effects on aquatic nitrification: experimental evidence and potential implications
}

\author{
Peter J. Lavrentyev ${ }^{1, * * *}$, Wayne S. Gardner ${ }^{2, * *}$, Jeffrey R. Johnson ${ }^{1}$ \\ ${ }^{1}$ University of Michigan, Cooperative Institute for Limnology and Ecosystem Research, 2200 Bonisteel Blvd, Ann Arbor, \\ Michigan 48109, USA \\ ${ }^{2}$ National Oceanographic and Atmospheric Administration, Great Lakes Environmental Research Laboratory, \\ 2205 Commonwealth Blvd, Ann Arbor, Michigan 48105, USA
}

\begin{abstract}
Experiments, using natural plankton collected from a eutrophic site in Saginaw Bay, Lake Huron (USA) and from a hypereutrophic wetland of southern Lake Erie (USA), were conducted to test the hypothesis that bacterivory can control aquatic nitrification rates. The dynamics of nitrogen and protists in these experiments revealed a consistent pattern: an increase in concentrations of nitrates due to oxidation of $\mathrm{NH}_{4}{ }^{+}$always followed the collapse of bacterivorous nanoplankton populations. This collapse was, in turn, caused by predation pressure of larger ciliates and metazooplankton. Experiments, using enrichment batch cultures maintained at near-ambient concentrations of $\mathrm{NH}_{4}{ }^{+}$, indicated that bacterivorous protists can inhibit nitrification directly by reducing bacterial numbers and indirectly by promoting bacterial aggregation. The latter experiments also suggest that feeding strategies of microbial grazers, e.g. suspension-feeding Spumella sp. versus surface-feeding Bodo saltans, may determine their grazing impacts on nitrifiers. Finally, ingestion rates of fluorescently labeled nitrifying bacteria (FLNB) by the natural planktonic assemblage from Saginaw Bay demonstrated that nanoflagellates were able to efficiently prey on low concentrations of FLNB. Our study suggests that previously neglected trophic factors may be of potential importance for mediating nitrification rates in the pelagic environment.
\end{abstract}

KEY WORDS: Nitrification Protozoa $\cdot$ Zooplankton · Bacterivory · Predation

\section{INTRODUCTION}

Nitrification, a fundamental process in aquatic environments, is mediated by 2 groups of obligatory autolithotrophic bacteria that use $\mathrm{NH}_{4}{ }^{+}$and $\mathrm{NO}_{2}^{-}$as their sole energy sources and $\mathrm{CO}_{2}$ as their main carbon source (Winogradsky 1890). The ammonium-oxidizers and nitrite-oxidizers are Proteobacteria (Woese et al. $1984 \mathrm{a}, \mathrm{b})$ that are most commoniy represented in the freshwater environment by the genera Nitrosomonas and Nitrobacter, respectively (Hall 1986). Most nitrifiers grow optimally in cultures at nitrogenous substrate concentrations ranging from 2 to $10 \mathrm{mM}$ (Bock et

\footnotetext{
•E-mail: peterl@utmsi.zo.utexas.edu

- Present address: University of Texas at Austin, Marine Science Institute, 750 Channelview Drive, Port Aransas,

Texas 78373, USA
}

al. 1986). Combined with the high energy cost of carbon fixation in nitrifiers via the Calvin cycle (Wood 1986) and photooxidation of their cytochrome $c$ by visible blue and UV light (Bock et al, 1986), these observations may suggest that the growth and metabolisms of nitrifying bacteria should be very slow at the $\mu \mathrm{M}$ to $n M$ concentrations of inorganic $N$ characteristic of most marine and freshwater systems.

Ambient populations of nitrifiers appear, however, to be well adapted to a wide range of environmental conditions. Studies of nitrification in marine pelagic environments, reviewed by Kaplan (1983) and Ward (1986), indicate that natural populations of nitrifiers can oxidize their substrates at rates several orders of magnitude higher than those predicted from pure cultures. Furthermore, nitrification was detected under $24 \mathrm{~h}$ light cycle incubations in the photic zone (Ward 1986), suggesting that light inhibition may be not so 
severe in the surface waters as previously believed (Yoshioka \& Sajo 1984). Nitrification occurs in such extreme environments as hot springs (Bock et al. 1989) and Antarctic ice (Arrigo et al. 1995). Although autolithotrophic nitrification is strictly aerobic, nitrifiers remain active at very low oxygen tensions (Lipschultz et al. 1990).

The biotic factors that have been studied with respect to nitrifying bacteria are mostly those affecting substrate availability and abiotic growth conditions. Nitrifiers can efficiently compete with phytoplankton for $\mathrm{NH}_{4}{ }^{+}$due to their high substrate affinities (Kaplan 1983, Ward 1986). Similar competition between aquatic nitrifiers and heterotrophic bacteria should occur because heterotrophs often compete with phytoplankton tor dissolved inorganic nutrients (Bratbak \& Thingstad 1985, Elser et al. 1995). At the same time, nitrifying activity in the pelagic zone positively correlates with the amount of labile organic matter (Hall 1986, Lipschultz et al. 1990), probably implying a dependency on $\mathrm{NH}_{4}{ }^{+}$regeneration. At the sedimentwater interface, microalgae compete with nitrifiers for $\mathrm{NH}_{4}{ }^{+}$(Rysgaard et al. 1995) and change their growth conditions by increasing both $\mathrm{pH}$ (Henriksen \& Kemp 1988) and $\mathrm{O}_{2}$ penetration (Risgaard-Petersen et al. 1994), whereas benthic macrofauna can accelerate nitrification by aerating sediments, regenerating $\mathrm{NH}_{4}{ }^{+}$, and producing PON (particulate organic nitrogen)-rich fecal pellets (Gardner et al. 1987. Henriksen et al. 1993).

Although nitrifying bacteria are susceptible to grazing (Fenchel \& Blackburn 1979, Meyer-Reil 1983, Henriksen \& Kemp 1988), direct evidence for a trophic control of aquatic nitrification is lacking. In both the marine and freshwater environments, planktonic protists (i.e. unicellular eukaryotic organisms capable of phagotrophy) play the pivotal role in consuming heterotrophic bacterial production (Azam et al. 1983, Sanders et al. 1989, Sherr et al. 1989) and recycling $\mathrm{NH}_{4}{ }^{+}$in the pelagic zone (Caron \& Goldman 1990, Selmer et al. 1993, Haga et al. 1995). In turn, the trophic cascade involving bacterivorous protists can profoundly affect bacterial community structure (Jürgens et al. 1994) as well as bacterial production (Rivkin et al. 1996) and community $N$ regeneration (Miller et al. 1995, Suzuki et al. 1996).

Our major goals were to test the hypothesis that bacterivory by planktonic protists can control nitrification rates and to determine whether this process can be mediated by changes in invertebrate community trophic structure. Specifically, we conducted experiments to address the following questions that arose as the study progressed:

(1) Are nitrification rates related to the compositional and density dynamics of the planktonic protist commu- nity and does the presence of metazooplankton affect this relationship?

(2) What is the 'unrestricted' (i.e. under no substrate competition/no predation pressure) effect of bacterivory on nitrification?

(3) Do differences in feeding strategies of bacterivores and grazing resistance in nitrifying bacteria affect nitrification rates?

(4) What is the potential for the natural planktonic assemblage and its major components to graze on nitrifying bacteria?

\section{MATERIAL AND METHODS}

Sampling sites. The natural plankton used in this study were collected from Saginaw Bay, Michigan, USA, and Old Woman Creek, Ohio, USA. Saginaw Bay is a large (about $82 \mathrm{~km}$ long and $42 \mathrm{~km}$ wide) bay extending off the western edge of Lake Huron. Its shallow ( $3.5 \mathrm{~m}$ mean depth) inner part receives large inflows of enriched waters from the Saginaw River and is considered to be eutrophic. Details of the bay ecosystem are provided by Nalepa \& Fahnenstiel (1995). Old Woman Creek, located in the southwestern shore of Lake Erie east of Sandusky Bay, is a shallow (ca $0.5 \mathrm{~m}$ mean depth) hypereutrophic coastal wetland that receives high inputs of allochthonous nutrients and organic matter from the surrounding agriculture (Kepner \& Pratt 1996 and references therein). The concentration of chlorophyll $a$ at the time of sample collection was 7.5 and $50.5 \mu \mathrm{g} \mathrm{l}^{-1}$ in Saginaw Bay and Old Woman Creek, respectively (J. F. Cavaletto, GLERL, pers. comm.).

Experimental design. Expt 1: To address Question 1 of this study we examined nitrification and protist dynamics in the presence and absence of net zooplankton in a bottle experiment. A flow diagram (Fig. 1) outlines the following experimental manipulations. Water was collected from Old Woman Creek $\left(15^{\circ} \mathrm{C}\right)$ and inner Saginaw Bay $\left(13.5^{\circ} \mathrm{C}\right)$ in October 1994 by submerging 201 polycarbonate carboys under the surface. The carboys were kept in insulated coolers in the laboratory for $2 \mathrm{~d}$, allowing water temperature to aradually reach $20^{\circ} \mathrm{C}$. Subsequently, 3.51 aliquots of the water were placed in four $4 \mathrm{l}$ acid-washed and distilled water-rinsed polycarbonate bottles and incubated in an indoor Percival incubator at $20^{\circ} \mathrm{C}$ in the dark.

By conducting the experiments in the dark we eliminated such strong factors as light inhibition and algal $N$ uptake. This approach allowed us to measure nitrification rates by simply tracing the concentrations of $\mathrm{NH}_{4}{ }^{+}$ and nitrates without using specific inhibitors and isotope dilution techniques that are based on the numer- 


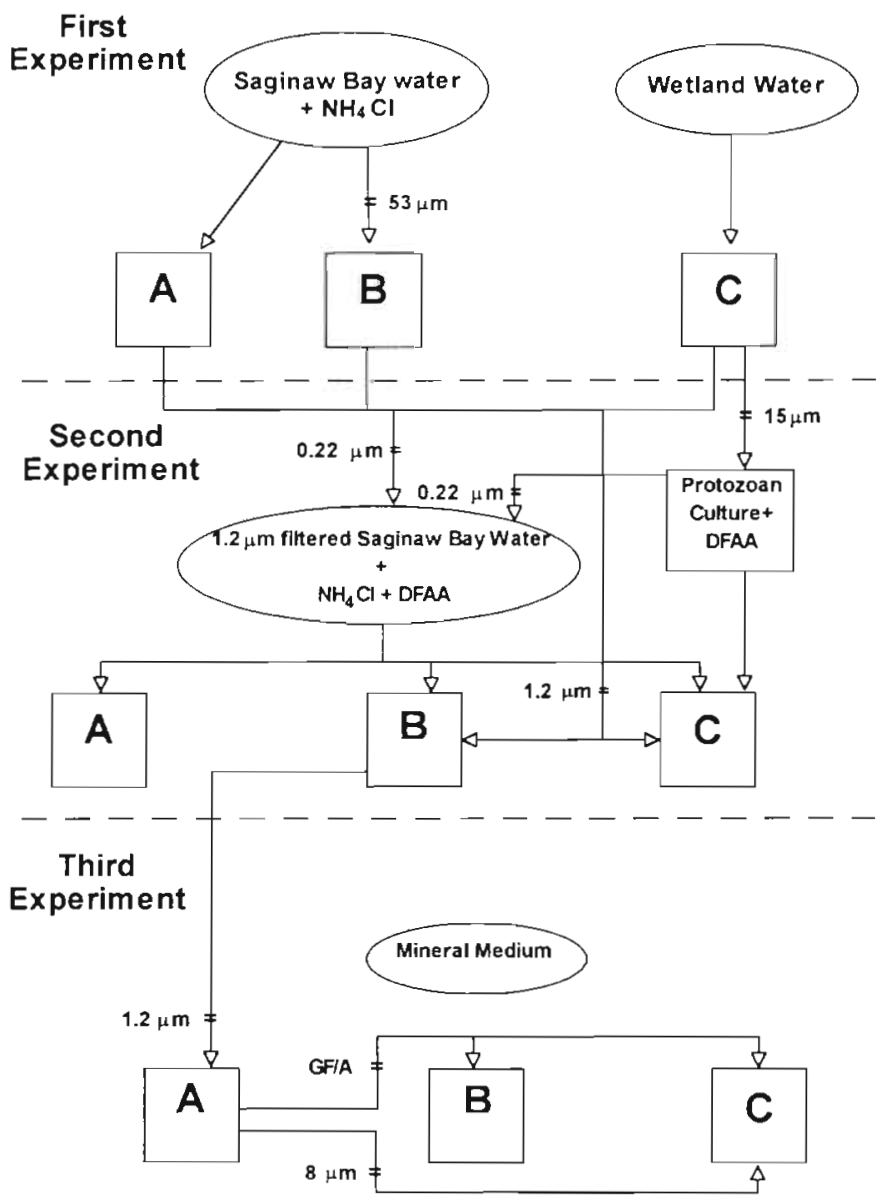

Fig. 1. Flow diagram outlining the experimental manipulations. Letters (A, B, C) refer to experimental treatments in Expts 1, 2, and 3 shown in Figs. 2, 3 and 4, respectively, and in Table 2

ous hard-to-test assumptions (see Ward 1986). All experiments were conducted at the same temperature to equalize its effects and ensure the fast growth of nitrifier populations. This temperature change was well within the range typical for the shallow coastal habitats of the experimental organisms. Our observations indicated no immediate change in the abundance or composition of planktonic organisms that could be associated with a temperature-induced stress.

Before incubation, Saginaw Bay water (Fig. 1A, B) was enriched with $4 \mu \mathrm{M} \mathrm{NH} \mathrm{NH}_{4} \mathrm{Cl}$ to give a total $\mathrm{NH}_{4}^{+}$ concentration of $6 \mu \mathrm{M}$. One of the bottles was filled with water pre-filtered through a $53 \mu \mathrm{m}$ mesh size Nitex net to remove zooplankton (Fig. 1B). Duplicate bottles with Old Woman Creek water were incubated without nutrient additions (Fig. 1C) because $\mathrm{NH}_{4}{ }^{+}$concentrations were already high (ca $30 \mu \mathrm{M})$. The concentrations of $\mathrm{NH}_{4}{ }^{+}$, nitrates $\left(\mathrm{NO}_{2}{ }^{-}+\mathrm{NO}_{3}{ }^{-}\right)$, and protists in the bottles were simultaneously monitored over time as described below. Zooplankton were collected from the carboys at the beginning and from the bottles at the end of experiment by passing $3.5 \mathrm{l}$ aliquots of water through a $53 \mu \mathrm{m}$ mesh size screen. Zooplankton from the bottle with filtered Saginaw Bay water were collected only at the end. The experiment was terminated when the concentration of $\mathrm{NH}_{4}{ }^{+}$dropped below detection (ca $0.2 \mu \mathrm{M}$ ).

Expt 2: To examine the effect of bacterivory on nitrification in the absence of predation pressure on bacterivores and substrate competition (Question 2) we conducted another bottle experiment. A mixed culture of bacterivorous protists was established by filtering the Old Woman Creek water through a $15 \mu \mathrm{m}$ mesh size Nitex net to remove metazoans and larger protists and then enriching the resulting filtrate with a mixture of amino acids (AA-S-18, Sigma) to provide an organic substrate for bacteria. The following manipulations were done to equalize conditions in experimental treatments and promote the growth of nitrifiers. Water from the first experiment was filtered through a $0.22 \mu \mathrm{m}$ pore size membrane filter, mixed with $0.22 \mu \mathrm{m}$ filtrate from the culture, diluted 1:1 with freshly collected and $1.2 \mu \mathrm{m}$ filtered Saginaw Bay water, and put into 3 clean 11 polycarbonate bottles. One bottle was used as a control (Fig. 1A). Aliquots of $1.2 \mu \mathrm{m}$ filtrate from the first experiment were added into the 2 remaining bottles (Fig. 1B, C), and the cultured bacterivorous flagellates and ciliates in the exponential phase were inoculated into 1 of these 2 bottles (Fig. 1C). Finally, the concentrations of $\mathrm{NH}_{4}{ }^{+}$and amino acids were adjusted to $10 \mu \mathrm{M}$ and about $4 \mu \mathrm{M}$, respectively, in all 3 bottles. Amino acids were added to prevent possible competition between heterotrophic and nitrifying bacteria for $\mathrm{NH}_{4}{ }^{+}$, assuming that heterotrophic bacteria would preferentially obtain $\mathrm{N}$ from amino acids (Kirchman et al. 1989). The bottles were incubated at $20^{\circ} \mathrm{C}$ in the dark. The concentrations of $\mathrm{NH}_{4}{ }^{+}$, nitrates, and protists were simultaneously monitored over time. As in the first experiment, the bottles were monitored until $\mathrm{NH}_{4}{ }^{+}$ fell below detection in any of the bottles.

Expt 3: The effects of grazing resistance of bacteria and feeding strategies of bacterivores on nitrification rates (Question 3) were examined in an enrichment batch culture of nitrifying bacteria. Synthetic freshwater (Lehman 1980; $20 \mathrm{mg} \mathrm{CaCl} 22 \mathrm{H}_{2} \mathrm{O}, 10 \mathrm{mg}$ $\mathrm{MgSO}_{4}, 20 \mathrm{mg} \mathrm{NaHCO}$ per liter of deionized water) enriched with $\mathrm{NH}_{4} \mathrm{Cl}$ to $20 \mu \mathrm{M}$ (final concentration) was used as a culture medium. The $\mathrm{pH}$, adjusted with $0.5 \mathrm{~N} \mathrm{NaOH}$, was 7.3 after sterilization. To enrich nitrifiers, water from the treatment without added grazers in Expt 2 (Fig. 1B) was filtered through a $1.2 \mu \mathrm{m}$ pore size filter and transferred (dilution 1:500) into a glass Erlenmeyer flask containing $500 \mathrm{ml}$ of medium and 
equipped with inoculation and sampling ports, and a sterile air intake. The flask was incubated at $20^{\circ} \mathrm{C}$ in the dark. The concentration of dissolved oxygen (DO) monitored with a DO meter remained relatively constant between 0.4 and $0.5 \mathrm{mM}$. Regular transfers into a fresh medium were done with a dilution factor of 1:20. After phagotrophic flagellates were detected, nitrogen concentrations and microbial numbers in the culture were monitored (Fig. 1A). Subsequently, 1 portion of the culture was filtered through a GF/A fiber glass filter (pore size ca $1.7 \mu \mathrm{m}$ ) to remove grazers and bacterial aggregates and a second portion was filtered through a $8 \mu \mathrm{m}$ pore size membrane filter to remove bacterial aggregates but leave grazers. The $5 \mathrm{ml}$ aliquots of resulting GF/A filtrate were added to 2 flasks containing $100 \mathrm{ml}$ of fresh medium (Fig. 1B, C) and 1 of the flasks was additionally inoculated with $5 \mathrm{ml}$ of the $8 \mu \mathrm{m}$ filtrate (Fig. 1C).

We measured grazing rates of flagellates that developed in the enrichment culture using fluorescently labeled bacteria (FLB; Sherr \& Sherr 1993) prepared from GF/A filtrates of the same culture. To make ingestion rate measurements, a $60 \mathrm{ml}$ sample of culture was taken on the 10th day after inoculation (Fig. 1A), spiked with pre-sonicated FLB at ca $15 \%$ to the total bacterial concentration, and incubated in a $75 \mathrm{ml} \mathrm{Er}$ lenmeyer flask at $20^{\circ} \mathrm{C}$ in the dark. Sub-samples were taken at $15 \mathrm{~min}$ intervals and preserved with sequential additions of acid Lugol's iodine $11 \%$ final concentration), a few drops of $3 \%$ sodium thiosulfate, and buffered formaldehyde ( $1 \%$ final concentration). Numbers of FLB in grazer cells were determined microscopically.

Expt 4: To examine the potential ability of the natural planktonic assemblage to graze on nitrifying bacteria (Question 4) we conducted a field grazing experiment in August 1995. Water was collected from the subsurface layer in the inner Saginaw Bay as described above. Net zooplankton were collected by slowly hauling a $30.5 \mathrm{~cm}$ diameter, $53 \mu \mathrm{m}$ mesh size net from $1 \mathrm{~m}$ to the surface. One third of the resultant $250 \mathrm{ml} \mathrm{zoo-}$ plankton sample was placed into a 11 clear polycarbonate bottle filled with $750 \mathrm{ml}$ of $53 \mu \mathrm{m}$ filtered lake water. Pre-sonicated FLB prepared from the enrichment culture (Expt 3) were dispensed into a 11 clean polycarbonate bottle. We added FLB at $4 \%$ of the total bacterial population to examine the potential ability of the natural planktonic assemblage to consume nitrifying bacteria at approximately natural proportions relative to total bacterioplankton in the pelagic zone. Given that the average size of ambient bacterial cells from Saginaw Bay was $0.42 \mu \mathrm{m}$ ESD (equivalent spherical diameter) at the time of experiment, the added FLB constituted ca $19 \%$ of the ambient bacterial $C$. The bottle was incubated in an outdoor incubator at ambi- ent temperature $\left(21^{\circ} \mathrm{C}\right)$ and about $50 \%$ of incident radiation. Before taking each sample, the water was gently but thoroughly mixed by inverting the bottle The rest of the FLB experiment was conducted as described above, except that an additional sample was taken at 10 min after FLB were added. Zooplankton were screened from the bottle on a $53 \mu \mathrm{m}$ mesh size screen at the end of the experiment. In addition to measuring species-specific grazing rates we used a slightly modified community approach based on the disappearance of FLB from the water over time (Landry et al. 1995).

Sample processing. Nutrient analyses: The concentrations of $\mathrm{NH}_{4}{ }^{+}$and amino acids (primary amines) were measured via high performance liquid chromatography (Gardner \& St John 1991). The total concentration of nitrates $\left(\mathrm{NO}_{2}{ }^{-}+\mathrm{NO}_{3}{ }^{-}\right)$was measured via a Technicon AutoAnalyzer using the standard column wet chemical procedure of nitrate reduction by a copper-cadmium reductor column (Armstrong et al. 1967).

Bacteria: In the enrichment culture (Expt 3), freesuspended bacterial cells collected onto a $0.22 \mu \mathrm{m}$ pore size black polycarbonate filter were counted under a Leitz Laborlux fluorescent microscope (magnification $\times 1000$ ) using acridine orange (Hobbie et al. 1977). Total bacteria were counted similarly in samples sonicated for 5 min to break up bacterial aggregates. Bacterial cell sizes were measured via scanning electron microscopy (SEM; Nation 1983, Bratbak 1993) under an Amray 1820I scanning electron microscope (magnification $\times 11500$ ) at an acceleration voltage of $10 \mathrm{kV}$. In the case of the field grazing experiment (Expt 4), ambient bacteria were counted using acriflavine (Bergstrom et al. 1986), and bacterial dimensions were measured using fluorescent spheres (Bratbak 1993). Allometric relationships (Norland 1993) were used to convert bacterial biovolume to carbon. Carbon estimates were then averaged. Specific growth rates of cultured bacteria $\left(r, \mathrm{~d}^{-1}\right)$ were estimated assuming the exponential growth $r=\ln \left(N_{t} / N_{0}\right) / t$, where $N_{0}$ and $N_{t}$ were abundance of organisms at the beginning and at the end of incubation period $t$. Their specific metabolic rates and the efficiency of autolithotrophic growth were estimated assuming the ratio of $\mathrm{NH}_{4}{ }^{+}$-oxidizers to $\mathrm{NO}_{2}{ }^{-}$-oxidizers of $1: 1$, and gross growth efficiencies of $10 \%$ (Wood 1986).

Protists and metazoa: Heterotrophic flagellates, preserved with cacodylate buffered glutaraldehyde $1 \%$ final concentration), were counted (magnification $\times 1000$ ) following the DAPI-staining (Porter \& Feig 1980). For enrichment experiments and grazing experiments, the entire filter area was scanned (magnification $\times 500$ ). Ciliates, preserved with acid Lugol's iodine (1\% final concentration), were counted in settling 
chambers under a Wild phase-contrast inverted microscope (magnification $\times 125$ to $\times 500$ ). In addition, protists were qualitatively examined in vivo and those from the bacterial culture were also examined under SEM. Protistan biomass was estimated from cell linear dimensions by approximating geometric solids and assuming carbon content of $21 \mathrm{fg} \mathrm{C} \mathrm{mm}^{-3}$ (Putt \& Stoecker 1989). Metazooplankton were counted and identified after narcotization with carbonated water and preservation with sucrose-formalin.

\section{RESULTS}

\section{Expt 1: nitrification and protist dynamics in the presence and absence of net zooplankton}

In Saginaw Bay water (Fig. 2A, B), numbers of the predominant ciliates Strobilidium (Rhimostrombidium) humile, Urotricha ristoi, U. pelagica, and Pelagostrombidium sp. gradually declined as the experiment progressed. The abundance of nanoflagellates, largely the chrysophyte Chromulina sp (ESD $4.3 \mu \mathrm{m}$ ), increased, peaking at the end of the second week of the experiment. In $53 \mu \mathrm{m}$ filtered Saginaw Bay water (Fig. 2B) the increase in abundance of nanoflagellates coincided with the appearance of the large (ESD $55.5 \mu \mathrm{m}$ ) choreotrichous ciliate Strobilidium (Rhimostrombidium) lacustris. This ciliate species reached its maximum by the 20 th day. The microflagellates Paraphysomonas sp. (ESD $18.2 \mu \mathrm{m}$ ) and Collodictyon triciliatum (ESD $12.0 \mu \mathrm{m}$ ) also appeared in Saginaw Bay water at that time. After Day 20, the protistan populations declined in both bottles. This trend was more pronounced in unfiltered water, where decreases in protistan numbers began earlier and resulted in their virtual disappearance by the end of the experiment. In Old Woman Creek water (Fig. 2C), the large (ESD $69.5 \mu \mathrm{m}$ ) ciliate Hypotrichidium conicum, which dominated protistan biomass in the initial sample, was replaced by rapidly growing populations of nano-sized flagellates (largely cryptophytes and euglenids, ESD 5.0 to $7.2 \mu \mathrm{m}$ ) and the scuticociliates Cyclidium sp. (ESD $12.5 \mu \mathrm{m}$ ) and Cinetochilium margaritaceum (ESD $17.8 \mu \mathrm{m})$. Nanoplankton peaked at the 5th day, coinciding with the occurrence of the large ciliates $\mathrm{Di}$ leptus sp. (ESD $40.0 \mu \mathrm{m}$ ) and Euplotes affinis (ESD $45.2 \mu \mathrm{m}$ ) and the euglenid flagellate Peronema sp. (ESD $10.4 \mu \mathrm{m}$ ). The protistan populations declined as fast as they developed, and had almost disappeared by the 12th day. In contrast, zooplankton abundances increased by the end of experiment in both Saginaw Bay and Old Woman Creek treatments (Table 1).

In unfiltered Saginaw Bay water, the concentration of $\mathrm{NH}_{4}{ }^{+}$gradually increased until the 20th day, when it

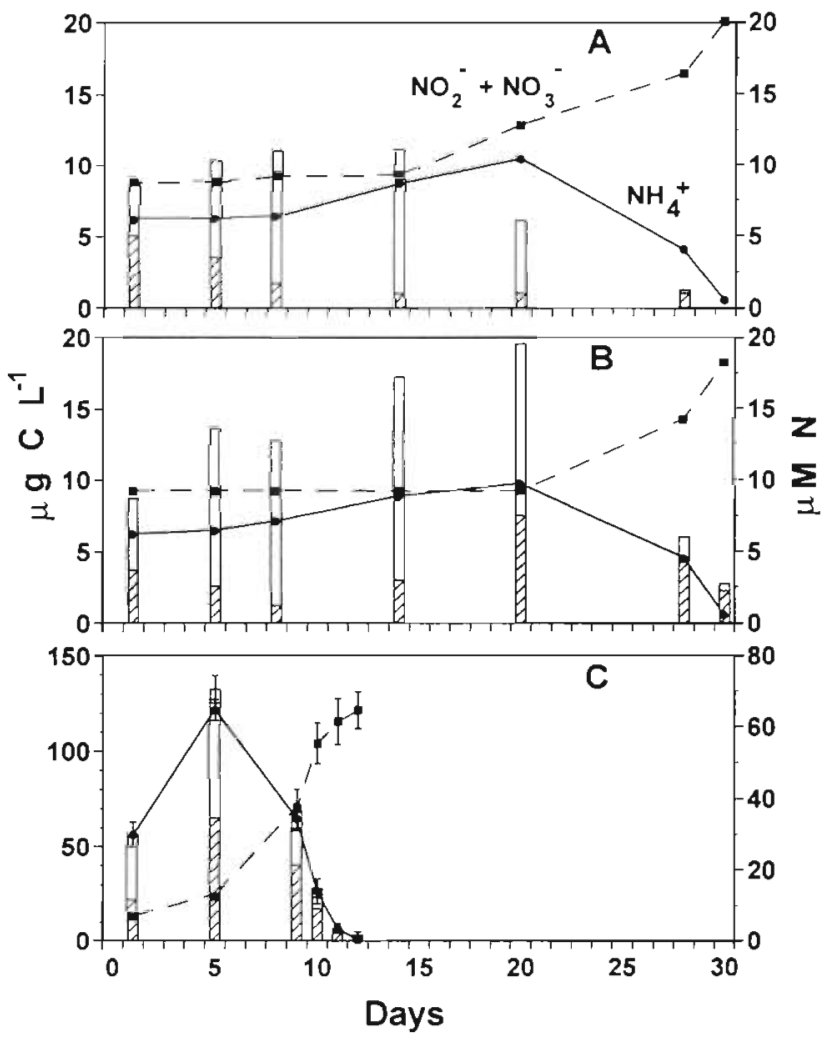

Fig. 2. Dynamics of $\mathrm{NH}_{4}{ }^{+}$(solid line with dots), nitrates $\left(\mathrm{NO}_{2}{ }^{-}\right.$ $+\mathrm{NO}_{3}{ }^{-}$, dashed line with squares), and biomass of protists (open bars: flagellates; striped bars: ciliates) in Expt 1: (A) in the bottle with unfiltered Saginaw Bay water, $(B)$ in the bottle with $53 \mu \mathrm{m}$ filtered Saginaw Bay water, and $(\mathrm{C})$ in duplicate bottles with unfiltered Old Woman Creek water ( \pm SE)

Table 1 Numbers (ind. $1^{-1} \pm \mathrm{SE}$ ) of net zooplankton at the beginning $\left(T_{0}\right)$ and the end ( $\left.T_{\text {Inc }}\right)$ of Expt 1. Incubation time: Saginaw Bay water, $30 \mathrm{~d}$; Old Woman Creek, $14 \mathrm{~d}$

\begin{tabular}{|c|c|c|}
\hline Taxon & $T_{0}$ & $T_{\text {ine }}$ \\
\hline \multicolumn{3}{|c|}{ Saginaw Bay unfiltered water } \\
\hline Bosmina longirostris & 12 & 44 \\
\hline $\begin{array}{l}\text { Cyclops sp. } \\
\text { (adults + copepodites) }\end{array}$ & 5 & 12 \\
\hline Copepod nauplii & 28 & 59 \\
\hline Keratella cohlearis & 34 & 67 \\
\hline Polyarthra sp. & 125 & 210 \\
\hline \multicolumn{3}{|c|}{ Saginaw Bay $53 \mu \mathrm{m}$ filtered water } \\
\hline Copepod nauplii & - & 24 \\
\hline Keratella cohlearis & - & 75 \\
\hline Polyarthra sp. & - & 1185 \\
\hline \multicolumn{3}{|c|}{ Old Woman Creek unfiltered water (duplicate treatments } \\
\hline Asplanchna priodonta & $5.5 \pm 1.2$ & $5.0 \pm 2.4$ \\
\hline $\begin{array}{l}\text { Acanthocyclops viridis } \\
\text { (adults + copepodites) }\end{array}$ & $4.5 \pm 0.18$ & $5.5 \pm 0.21$ \\
\hline Bosmina sp. & $12.1 \pm 1.0$ & $17.8 \pm 0.88$ \\
\hline Chydorus sp. & $<0.2$ & - \\
\hline Copepod nauplii & $86.0 \pm 6.4$ & $120.5 \pm 5.5$ \\
\hline $\begin{array}{l}\text { Diaptomus sp. } \\
\text { (adults + copepodites) }\end{array}$ & $22.3 \pm 0.44$ & $27.6 \pm 0.5$ \\
\hline
\end{tabular}


began to decrease falling into nanomolar concentrations by the 30 th day (Fig. $2 \mathrm{~A}$ ). The concentration of nitrates did not show any appreciable changes until the 15th day when it began to increase, reaching a rate of $1.5 \mu \mathrm{M} \mathrm{d}^{-1}$ at the end of experiment. The dynamics of nitrogen in filtered Saginaw Bay water was basically the same as in unfiltered water, except that there was a $5 \mathrm{~d}$ lag in the increase in nitrates (Fig. 2B). The final concentration of these compounds was slightly higher in unfiltered water ( $20 \mathrm{vs} 18 \mu \mathrm{M}$ ). In contrast to these slow changes, the dynamics of nitrogen in the Old Woman Creek water was quite dramatic. There was a rapid increase in the concentration of $\mathrm{NH}_{4}{ }^{+}$from 30 to almost $70 \mu \mathrm{M}$ within a few days, which was followed by even sharper decrease in $\mathrm{NH}_{4}{ }^{+}$and corresponding accumulation of nitrates at a rate of up to $20 \mu \mathrm{M} \mathrm{d}^{-1}$ (Fig. 2C). Despite this striking difference, all the treatments revealed a similar pattern: $\mathrm{NH}_{4}{ }^{+}$concentrations generally followed dynamics of protists, while accumulation of nitrates followed the collapse in their populations.

\section{Expt 2: isolated effect of bacterivory on nitrification}

In the control treatment (not enriched with bacteria from the first experiment; Fig. 3A), the concentration of $\mathrm{NH}_{4}{ }^{+}$increased steadily during the experiment, while the concentration of nitrates changed little, except for a slight increase at the end of experiment. At the same time, a 2-fold difference in accumulation of these compounds ( 65 vs $33 \%$ of the initial level) was observed between treatments without (Fig. 3B) and with (Fig. 3C) the addition of an inoculum from a mixed culture of nanoplankton-sized bacterivorous protists mostly

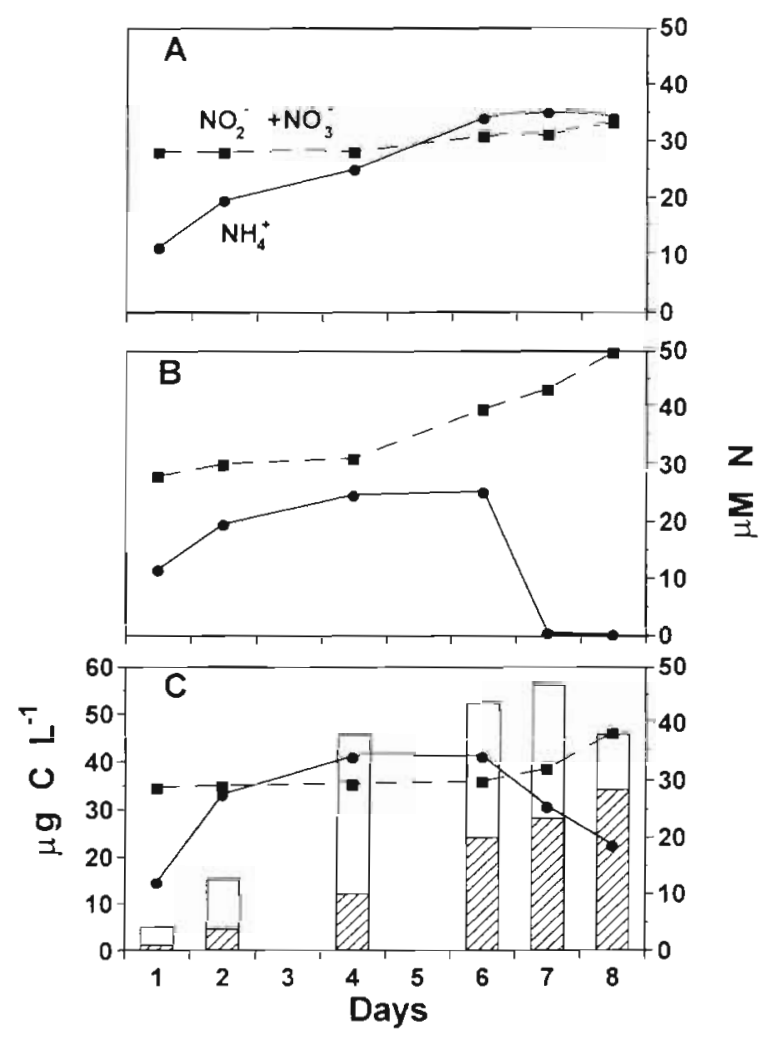

Fig. 3. Dynamics of $\mathrm{NH}_{4}{ }^{+}$, nitrates, and protists in Expt 2. (A) Control, (B) addition of $1.2 \mu \mathrm{m}$ filtrate from Expt 1, and (C) the same plus an inoculum of protist culture. Legend as in Fig. 2

represented by Cyclidium sp., C. marganitaceum, Bodo saltans, Spumella sp., and Goniomonas sp. The carnivorous ciliate Dileptus sp. developed in the treatment with the inoculum by the end of incubation.

Table 2. Dynamics of nitrification rates and selected microbial parameters in an enrichment batch culture of nitrifying bacteria (Expt 3). Letters A, B, and C denote experimental treatments (for explanation see Fig. 1 and the text). $C_{p}$ : increase in bacterial biomass over time; $C_{f}$ : fixed carbon (assuming gross growth efficiency of $\left.10 \%\right)_{i} N_{0}$ : oxidized nitrogenous substrate. The range of the published specific rates and ratios for ammonium- (upper row) and nitrite-oxidizing (lower row) bacteria are given after Kaplan (1983), Glover (1985), Bock et al. (1986) and Ward (1986). The range of in situ nitrification rates in the pelagic zone of freshwater lakes is given after Hall (1986)

\begin{tabular}{|c|c|c|c|c|c|c|c|c|}
\hline $\begin{array}{l}\text { Treatment } \\
\text { period (d) }\end{array}$ & 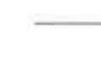 & 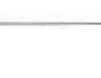 & A & 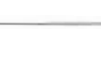 & - & B & C & $\begin{array}{l}\text { Published } \\
\text { data }\end{array}$ \\
\hline $\begin{array}{l}\text { Nitrification rate } \\
\left(\mu \mathrm{M} d^{-1}\right)\end{array}$ & 2.12 & 1.15 & 0.52 & 0.42 & 0.38 & 18.66 & 8.9 & $0-78.5$ \\
\hline $\begin{array}{l}\text { Specific nitrification rate } \\
\text { (fmol } N \text { cell } \\
-11 h^{-1} \text { ) }\end{array}$ & 3.16 & 1.36 & 0.52 & 0.39 & 0.33 & 70.0 & 48.2 & $\begin{array}{r}0.9-83 \\
0.24-42\end{array}$ \\
\hline $\begin{array}{l}\text { Bacterial specific growth rate } \\
\left(d^{-1}\right)\end{array}$ & 0.17 & 0.06 & 0.04 & 0.02 & 0.015 & 2.53 & 1.30 & $\begin{array}{l}0.03-2.67 \\
0.01-1.66\end{array}$ \\
\hline $\begin{array}{l}\text { Carbon yield from nitrification } \\
\left(\mathrm{C}_{\mathrm{p}}: \mathrm{N}_{\mathrm{o}} \mathrm{mmol}: \mathrm{mol}\right)\end{array}$ & 4.7 & 4.5 & 7.1 & 5.9 & 6.2 & 1.6 & 1.85 & $\begin{array}{c}4-7 \\
1.4-3.1\end{array}$ \\
\hline $\begin{array}{l}\text { Utilization efficiency } \\
\left(\mathrm{N}_{\mathrm{o}}: \mathrm{C}_{\mathrm{f}} \text { mol:mol) }\right.\end{array}$ & 21.3 & 22.2 & 14.1 & 16.9 & 16.1 & 62.5 & 54.5 & $\begin{array}{c}5-42 \\
25-132\end{array}$ \\
\hline
\end{tabular}


Expt 3: grazing resistance of bacteria and feeding strategies of bacterivores

From 85 to $90 \%$ of the enrichment culture consisted of uniform rod-shaped bacteria (ESD 0.47 to $0.51 \mu \mathrm{m}$ ). The rates of $\mathrm{NH}_{4}{ }^{+}$uptake, and corresponding accumulation of nitrates in the culture (which was regularly transferred into a fresh medium), were relatively constant at ca $20 \mu \mathrm{M} \mathrm{d}^{-1}$ (the initial concentration of $\mathrm{NH}_{4}{ }^{+}$ was always set at $20 \mu \mathrm{M}$ ) for several weeks until they fell to ca $2 \mu \mathrm{M} \mathrm{d}^{-1}$ as the flagellates Spumella sp. (ESD $2.0 \mu \mathrm{m}$ ) and Bodo saltans (ESD $3.9 \mu \mathrm{m}$ ) appeared in the culture (Table 2A). At the end of the $20 \mathrm{~d}$ incubation the concentration of $\mathrm{NH}_{4}{ }^{+}$decreased from the initial $20 \mu \mathrm{M}$ to $3.4 \mu \mathrm{M}$, while nitrates increased from ca 1 to $19.2 \mu \mathrm{M}$ (Fig. 4A). Shortly after the occurrence of flagellates, bacteria began to form large $(18$ to $>70 \mu \mathrm{m}$ ESD) gelatinous colonies. The ratio of flagellate to bacterial $\mathrm{C}$ and the proportion of aggregated bacteria both increased over time (Fig. 4A), whereas nitrification rates gradually decreased down to $0.38 \mu \mathrm{MN}$ $\mathrm{d}^{-1}$ (Table 2A). The specific $\mathrm{N}$-oxidation metabolism of bacteria, estimated assuming that $\mathrm{NH}_{4}{ }^{+}$-oxidizers and $\mathrm{NO}_{2}{ }^{-}$-oxidizers were numerically equal, decreased from 3.16 to $0.33 \mathrm{fmol} \mathrm{N}$ cell $^{-1} \mathrm{~h}^{-1}$, and their net specific growth rates decreased from $0.168 \mathrm{~d}^{-1}$ to $0.015 \mathrm{~d}^{-1}$. The 2 latter variables were tightly correlated $(r=0.99, p<$ 0.001 and $r=0.98, p<0.01$, respectively) with nitrification rates. The efficiency of autolithotrophic growth expressed as the ratios of $\mathrm{N}$ oxidized to $\mathrm{C}$ produced and $C$ fixed did not change appreciably, even though the average bacterial cell volume increased by about $11 \%$ by the end of incubation.

The growth of the initially predominant Spumella sp. slowed down as bacterial clumping progressed, whereas the abundance and growth rates of Bodo saltans increased. When the grazers and bacterial clumps were removed by differential filtration, and the resulting filtrates were transferred into a fresh medium, nitrification immediately increased to the initial rate of $18.66 \mu \mathrm{M} \mathrm{N} \mathrm{d}^{-1}$ (Table $2 \mathrm{~B}$ ). The corresponding net specific growth rate of bacteria of $2.53 \mathrm{~d}^{-1}$ and their specific $\mathrm{N}$-oxidation rate of $70 \mathrm{fmol} \mathrm{N}$ cell-1 $\mathrm{h}^{-1}$ were much higher compared to the previous incubation, whereas the parameters indicating growth efficiency were lower. Intentional inoculation of flagellates into the new culture (Table 2C), however, lowered the total and cell-specific rates of nitrification by $52 \%$ and $30 \%$, respectively, and bacterial net specific growth rate by ca $50 \%$. The autolithotrophic growth-efficiency parameters remained at about the level observed in the ungrazed treatment. About $18 \%$ of the total bacterial population in the new culture occurred in aggregates when flagellates were present versus less than $2 \%$ when they were absent (Fig. 4B, C).
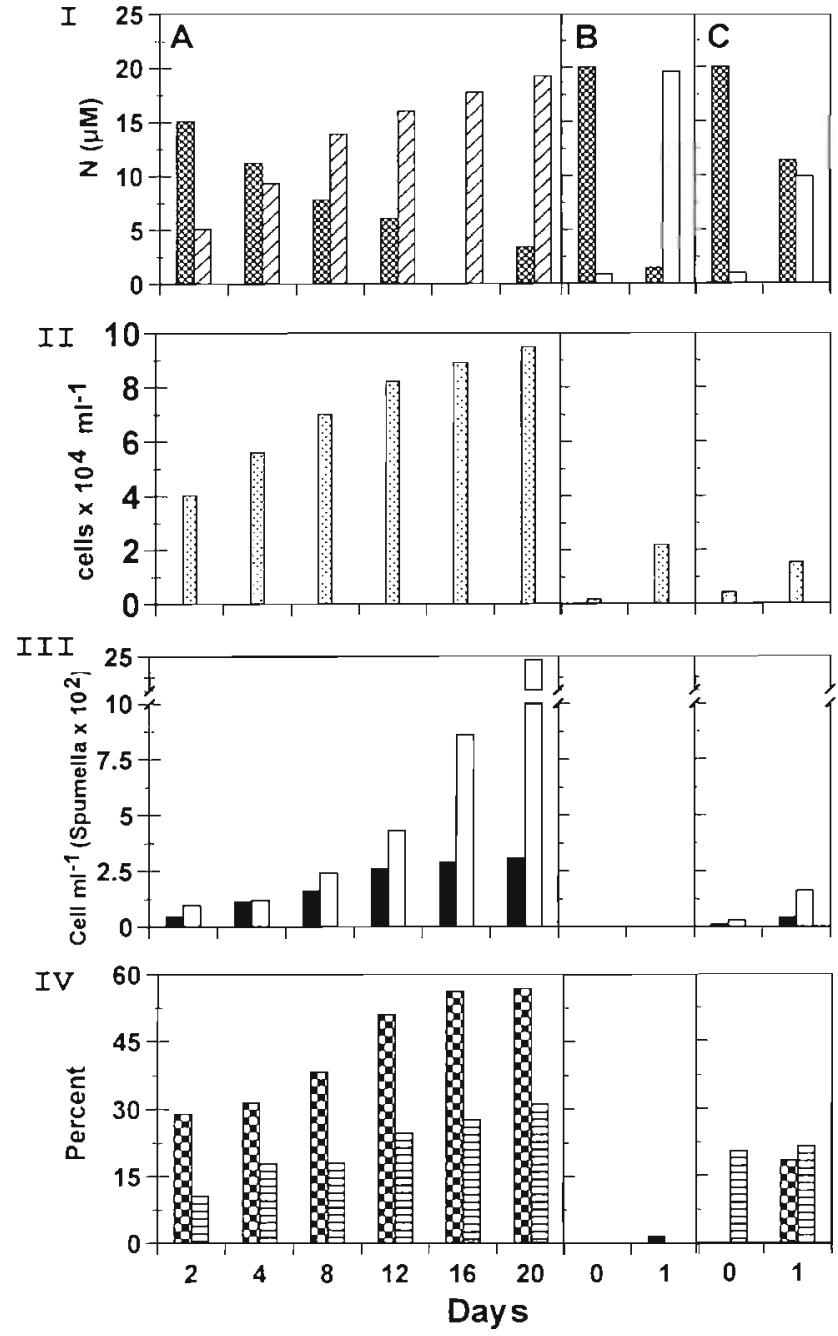

Fig, 4. Dynamics of: (I) dissolved inorganic nitrogen $\left(\mathrm{NH}_{4}{ }^{+}\right.$: shaded bars; nitrates: striped bars); (II) bacteria (shaded bars); (IIl) flagellates (Spumella sp:: solid bars; Bodo saltans: empty bars); and (IV) the ratios of bacterial aggregates to the total bacterial abundance (shaded bars) and flagellate to bacterial biomass (striped bars) in the enrichment culture (Expt 3). Letters $(A, B, C)$ refer to experimental treatments described in the text

A FLB experiment conducted on the 10th day yielded grazing rates of $5 \pm 0.6$ and $1.2 \pm 0.4$ bacteria flagellate $^{-1} \mathrm{~h}^{-1}$ for Spumella sp. and Bodo saltans, respectively. Given respective specific growth rates of 0.118 and $0.140 \mathrm{~d}^{-1}$ for the 2 flagellates, their gross growth efficiencies (GGE) were ca 30 and $50 \%$, respectively. Based on their abundance and specific growth rates $\left(1.69 \mathrm{~d}^{-1}\right.$ B. saltans and $1.29 \mathrm{~d}^{-1}$ Spumella sp.) and the above GGE, the combined daily carbon requirement of the flagellates added back to the fresh medium was $300 \mathrm{pg} \mathrm{C} \mathrm{ml} \mathrm{C}^{-1} \mathrm{~d}^{-1}$ or $9.94 \times 10^{3}$ cells ml $\mathrm{m}^{-1}$ $\mathrm{d}^{-1}$ that was approximately equal to the difference in total bacterial cell yield between the grazer (Fig. 4B) and control treatments (Fig. 4C). 


\section{Expt 4: grazing on nitrifying bacteria by natural plankton}

The abundance (ind. $\mathrm{l}^{-1}$ ) of plankton in Saginaw Bay sample was as follows: heterotrophic flagellates $1.25 \times$ $10^{6}$, ciliates $1.13 \times 10^{4}$, rotifers $2.15 \times 10^{2}$, copepod nauplii 65 , cyclopoid copepods (adults and copepodites) 10.5, calanoid copepods (adults and copepodites) 3.2, cladocera 17.5 , Dreissena larvae 62 . The ambient concentration of bacteria in the bay water was $4.6 \times 10^{6}$ cells $\mathrm{ml}^{-1}$. Based on changes in FLB concentration over time in the experimental vessel, the total community grazing rate on FLB was $5.4 \times 10^{3} \mathrm{FLB} \mathrm{ml}^{-1} \mathrm{~h}^{-1}$ or nearly $3 \%$ of the added amount. Because Lugol's color was

Table 3. Qualitative data on ingestion of fluorescently labeled nitrifying bacteria (FLNB) by planktonic protists and metazooplankton from Saginaw Bay (Expt 4)

\begin{tabular}{|c|c|}
\hline Species & Ingested FLNB \\
\hline \multicolumn{2}{|l|}{ Ciliates } \\
\hline Askenasia volvox & No \\
\hline Cyclidium sp. & Yes \\
\hline Disematostoma sp. & No \\
\hline Pelagohalteria viridis & Yes \\
\hline Pelagostrombidium sp. & Yes \\
\hline P. fallax & No \\
\hline Prorodon sp. & No \\
\hline Pseudobalanion planktonicum & No \\
\hline Strobilidium sp. & Yes \\
\hline S. lacustris & Yes \\
\hline S. humile & Yes \\
\hline Urostyla sp. & No \\
\hline Urotricha furcata & No \\
\hline U. pelagica & No \\
\hline U. ristoi & Yes \\
\hline Vaginicola sp. & No \\
\hline Vorticella anabaenae & Yes \\
\hline \multicolumn{2}{|l|}{ Flagellates } \\
\hline Bodo sp. & Yes \\
\hline Chromulina sp. & Yes \\
\hline Codosiga sp. & Yes \\
\hline Cryptomonas sp. & Yes \\
\hline C. erosa & No \\
\hline Chrysochromulina parva & No \\
\hline Ceratium herudinella & No \\
\hline Dynobrion bavaricum & Yes \\
\hline Gymnodinium helveticum & No \\
\hline Ochromonas nana & Yes \\
\hline Peridizicim sp. & No \\
\hline Rhodomonas minuta & No \\
\hline Peranema sp. & Yes \\
\hline Paraphysomonas sp. & Yes \\
\hline \multicolumn{2}{|l|}{ Zooplankton } \\
\hline Bosmina longirostris & Yes \\
\hline copepod nauplia & Yes \\
\hline Cyclops sp. & No \\
\hline Diaptomus sp. & No \\
\hline Dreissena larvae & Yes \\
\hline Filinia sp. & Yes \\
\hline Keratella cohlearis & Yes \\
\hline Polyarthra sp. & No \\
\hline
\end{tabular}

not adequately removed with thiosulfate in some chlorophyll-bearing protists, and because several species were not found in sufficient numbers, it was only possible to examine their FLB uptake qualitatively (Table 3). However, we were able to estimate specific ingestion rates for flagellates and the choreotrichous ciliate Strobilidium humile (ESD $20.1 \mu \mathrm{m}$ ) which formed nearly $70 \%$ of the total ciliate abundance. The numbers of ingested FLB in protists increased linearly over time $(\mathrm{r}=0.94, \mathrm{p}<0.05)$. For flagellates these numbers ranged from 0.8 cells flagellate $\mathrm{h}^{-1}$ in the Ochromonas nana (ESD $2.3 \mu \mathrm{m}$ ) to 20.2 cells flagellate $^{-1} \mathrm{~h}^{-1}$ in Paraphysomonas sp. (ESD $12.9 \mu \mathrm{m}$ ), averaging 2.78 cells flagellate ${ }^{-1} \mathrm{~h}^{-1}$. S. humile ingested 89.4 cells ciliate ${ }^{-1} \mathrm{~h}^{-1}$. Based on the abundance of these protists their contributions to the total grazing loss of FLB were 64 and $12 \%$ for flagellates and S. humile, respectively.

\section{DISCUSSION}

\section{Direct effect: grazing mortality in nitrifiers}

The results of this study point out the potential ability of planktonic protists to control nitrifier populations via grazing. In Expt 4, a significant proportion of FLB was removed by the natural assemblage of flagellates and nanociliates despite the low concentration of labeled prey. This fact may suggest that protists would efficiently prey on nitrifying bacteria even in the environments where these bacteria form only a small proportion of the total bacterial assemblage. Since the FLB used in our experiments were large compared to ambient bacteria from Saginaw Bay, they may have been selectively grazed (Chrzanowski \& Simek 1990, Gonzalez et al, 1990). Because of the necessity to accommodate intracytoplasmic membranes, nitrifier cells tend to be larger then cells of most other planktonic bacteria. Hence, the above experimental situation may have been not too far from reality. This aspect of the protist-nitrifier interactions remains to be clarified in further studies.

The results of Expt 2 imply that bacterial grazing was the major factor causing $\mathrm{N}$-oxidation rates to be lower in the treatment with added protists. A 2-fold decrease in nitrification rate and the corresponding decrease in the bacterial cell yield observed in the grazer treatment in Expt 3 provide further evidence for grazing mortality of nitrifiers being a major cause of lower nitrification rates in the presence of protists. Also, the bacterial growth rates found here in the absence of grazers were close to those reported for natural assemblages of heterotrophic bacteria (Coveney \& Wetzel 1995). This observation implies that 
protistan bacterivory may be partially responsible for the 'low growth rates' of ambient populations of nitrifiers that have been previously observed (Hall 1986 and references therein). Thus, our findings are consistent with the idea that nitrification rates may be directly affected by protistan bacterivory.

Trophic interactions involving nitrifiers previously studied in soils and activated sludge provide useful data for comparison with our data, even though in many aspects the above 2 environments are different from the aquatic environments. Predominantly filterfeeding protists were able to remove a large proportion of free-suspended nitrifying bacteria in the biofilm reactor, but the 2 -fold increase in nitrification rates was observed only after rotifers grazing upon attached bacteria were inhibited (Lee \& Welander 1994). In contrast, no significant change in nitrification rates was observed in a soil chemostat culture despite a 70 to $80 \%$ reduction in numbers of free-suspended nitrifiers caused by selective protistan grazing. This result was attributed to the stimulating effect of bacterivory on the nitrifier cell-specific activities (Verhagen \& Laanbroek 1992). Although stiff competition between nitrifiers and heterotrophic bacteria for $\mathrm{NH}_{4}{ }^{+}$under high $\mathrm{C}: \mathrm{N}$ ratios in the latter study may have caused this difference, it remains unclear whether the only grazer present in the soil culture, the flagellate Adriomonas peritocrescens, was able to efficiently handle attached nitrifier cells. These results should draw our attention to the potential effects of bacterial behavior and invertebrate grazing strategies on nitrification.

\section{Indirect effects: grazing resistance and feeding modes}

Our findings also suggest that protists could indirectly reduce nitrification rates via forcing bacteria to grow in aggregates. The tendency of nitrifiers to form large colonies surrounded by gelatinous slime material first noted by Winogradsky (1890) has been frequently observed in enrichment cultures and activated sludge (Prosser 1986). This slime material was thought to protect nitrifiers from unfavorable conditions, specifically from high $\mathrm{pH}$ (Cox et al. 1980). The proportional increase in bacterial aggregates with the increasing ratio of protistan to bacterial carbon (Table $2 \mathrm{~A}$ ) and the occurrence of the bacterial aggregates after inoculation of the flagellates both strongly suggest that the bacterial clumping was related to bacterivorous activities. Aggregation in response to grazing has been repeatedly observed in heterotrophic bacteria in activated sludge (Curds 1982) and cultures (Patterson 1990) as well as in experiments using natural bacterioplankton (e.g. Van Wambeke \& Bianchi 1985, Caron et al. 1988). Bacterial growth in aggregates was incorporated as a part of the concept of grazing resistant bacteria (Jürgens \& Güde 1994), where it was largely associated with protists. The extracellular enzyme activities observed in bacterivorous protists (Simek et al. 1994) are likely to have an allelochemic effect on bacterial behavior, but the exact mechanism triggering bacterial clumping remains to be studied.

Since nitrifiers tend to use aggregation as a refuge from grazing, the overall impact of bacterivory may depend upon the ability of grazers to adapt to these changes in bacterial behavior. The occurrence of Spumella sp. at the initial stage of incubation and the following development of Bodo saltans are consistent with the idea that these species are adapted to feed upon free-suspended and attached bacteria, respectively (Caron 1987, Sibbald \& Albright 1988). Our grazing experiment using dispersed FLB likely yielded a conservative estimate of $B$. saltans ingestion rates, taking into account its feeding patterns. On the other hand, this mechanism may explain the higher growth rates of $B$. saltans despite its larger cell volume as compared to Spumella sp. The proportional increase in aggregates observed in Expt 3 corresponded to decreasing bacterial nitrification activity. Although this decrease may have been related to the physiological changes in the aging culture (Glover 1985), a decrease in the active cell surface due to the growth in aggregates could also cause this result. Aggregated Nitrobacter cells had lower activity due to the development of the slime layer that was only found in large older aggregates but not in young small colonies (Prosser 1986). The latter result could explain why bacterial cell-specific nitrification activity in Expt 3 became much higher in the fresh medium, even in the presence of grazers, after the old large aggregates had been removed. The growth in aggregates as a general pattern of bacterial behavior usually occurs when the concentration of substrate is not a limiting factor (Jürgens \& Güde 1994).

We did not attempt to accurately determine abundance of nitrifying bacteria in this pilot study because the conventional most probable number and immunofluorescence techniques used for their enumeration often yield numbers that show little correlation with the observed ambient nitrifying activities (Hall 1986). The polymerase chain reaction assay recently adapted for detecting nitrifiers in the natural bacterial assemblages (Derange \& Bardin 1995, Voytek \& Ward 1995) appears to overcome this problem but is not yet refined. Thus, as mentioned above, we assumed that $\mathrm{NH}_{4}{ }^{+}$-oxidizers and $\mathrm{NO}_{2}{ }^{-}$-oxidizers were numerically equal in our enrichment culture, even though in fact their physiological requirements may differ as well as their ambient distribution (Ward 1986). 
In addition, a part of the culture may have consisted of heterotrophic bacteria since soluble organic compounds exuded by nitrifiers may support the growth of a small heterotrophic bacterial population in a pure inorganic medium (Rittman et al. 1994). These bacteria could develop as the culture ages and organic compounds accumulate (treatment A). Also, we could expect bacterial carbon yield per $\mathrm{N}$ oxidized to increase with the increasing proportion of bacteria growing on substrate other then $\mathrm{NH}_{4}{ }^{+}$or $\mathrm{NO}_{2}{ }^{-}$. However, this variable remained relatively constant (Table $2 \mathrm{~A}$ ). The tight correlation between net specific growth rates of bacteria and nitrification rates in this treatment also implies the absence of significant changes in bacterial composition over time. Because of the above factors, our calculated rates are conservative. For example, if we assume that $50 \%$ of the enrichment culture consisted of bacteria other than nitrifiers, the specific nitrification rate observed in treatment $B$ would increase to a value that is almost twice as high as the maximum published specific nitrification rates (Table 2). Further, the N:C ratios estimated for the enrichment culture are well within the range reported in the literature. However, if we use the above assumption of $50 \%$ values of the culture due to heterotrophs, these ratios in treatments $B$ and $C$ would increase to unrealistically high values for a mixed culture of $\mathrm{NH}_{4}{ }^{+}$-oxidizers and $\mathrm{NO}_{2}{ }^{-}$-oxidizers. Combined with the morphological homogeneity of bacterial cells, frequent culture transfers, and the simultaneous accumulation of nitrates with $\mathrm{NH}_{4}{ }^{+}$ uptake, this observation indicates that nitrifying bacteria may have constituted a large fraction of the culture.

Most importantly, heterotrophic bacteria growing in a mineral medium are almost certainly C-limited, and, therefore, they are unlikely to compete with nitrifiers for inorganic nitrogen. Hence, independent of their proportion in the enrichment culture (Expt 3), heterotrophs were not responsible for the observed changes in nitrification rates. In contrast, addition of bacterivores always lowered these rates in this and other experiments. Interestingly, the maximum values of cellspecific $\mathrm{N}$-oxidation activity and carbon yield per unit of $\mathrm{N}$ oxidized were similar to those reported for the nitrifiers grown in pure cultures at millimolar substrate concentudions (Table 2). This result may suggest that substrate affinity of nitrifying bacteria in our experiments remained close to that of the original bacteria.

\section{Cascading top-down effects: importance of taxonomic composition}

The results of Expt 1 suggest that trophic cascades involving bacterivorous (mostly nano-sized) protists, larger protists, and metazooplankton can affect nitrifi- cation rates. The occurrence of the specialized bacterivorous scuticociliates may partially explain the rapid dynamics in the water from Old Woman Creek as their specific ingestion rates may be 50 times higher than those of nanoflagellates (e.g. Simek et al. 1994). High numbers of these ciliates found in the wetland water are typical for hypereutrophic situations (Beaver \& Crisman 1989, Christoffersen et al. 1990). In contrast, nanoflagellates were the major bacterial grazers in Saginaw Bay water as was observed in Expt 4. Similarly, nanoflagellates played the leading part in consuming bacteria in Lake Michigan (Carrick et al. 1991) as well as in other waters of low or moderate productivity (Gaedke \& Straile 1994, Sommaruga \& Psenner 1995)

Bacterivory has been reported in rotifers (Sanders et al. 1989, Ooms-Wilms et al. 1995), cladocera (Vaqué et al. 1992, Burns \& Schallenberg 1996), and in copepod nauplii (Roff et al. 1995). Some metazoa from Saginaw Bay contained ingested FLB in Expt 4 (Table 3). However, none of the zooplankton species in this study should be considered to be highly efficient bacterial grazers based on construction of their food gathering structures (Vanderploeg 1994). On the other hand, the same or similar zooplankton species prey upon protists (Hartmann et al. 1993, Jack \& Gilbert 1993, Sanders et al. 1994). The grazing control of nanoheterotrophs by planktonic microciliates is also well documented (e.g. Bernard \& Rassoulzadegan 1990, Verity 1991).

The direct and indirect grazing impacts of protists on nitrification and trophic interactions with metazoa discussed above suggest that the consistent patterns observed in the dynamics of protists and nitrification rates in Expt 1 are unlikely the result of simple coincidence. A plausible scenario for the observed dynamics is as follows: (1) die-offs of phytoplankton at the beginning of the dark incubation resulted in disappearance of most algivorous ciliates and produced large quantities of labile organic material, fostering development of heterotrophic bacteria; (2) heterotrophic nanoplankton (HNANO) relieved from ciliate grazing pressure thrived at the plentiful bacterial substrate; (3) depletion of this substrate and increases in omnivorous mesoznnnlankton in unfiltered water, or larger, potentially carnivorous ciliates, flagellates, and rotifers in filtered water, removed HNANO; (4) these predators were not efficient in filtering bacteria-sized particles and allowed the nitrifiers to proliferate.

If the above scenario is true, the cascading top-down effect of zooplankton on nitrifying bacteria would resemble those previously described to mediate the structure and activity of heterotrophic bacterioplankton (Jürgens et al. 1994, Rivkin et al. 1996). This similarity should not be unexpected as nitrifiers are a sub- 
set of the total bacterial assemblage. It is important to note, however, that the consequences of top-down impacts on nitrifying and heterotrophic bacteria may be different because of the difference in their physiology and functions in the ecosystem. Protist grazing upon heterotrophic bacteria, as portrayed in numerous studies, crops bacterial production and recycles nutrients for algal use, whereas grazing upon nitrifiers, as follows from our experiments, may modify nitrification rates and thus affect the biogeochemical cycle of nitrogen. In an ambient multistep food web, the composition of crustacean zooplankton may also be important: predominance of copepods will increase predation pressure on larger ciliates (Wiackowski et al. 1994, Burns \& Schallenberg 1996), while cladocera will have a strong impact on nanoplankton (Massana et al. 1994, Pace \& Vaqué 1994, Gasol et al. 1995). The survival rates and, therefore, potential trophic impacts of protists under predation pressure will also depend on their swimming abilities and growth rates (Gilbert 1994, Lavrentyev et al. 1995). Occasionally, trophic interactions between similarly sized protists may be also important (e.g. Hansen 1991).

\section{Potential implications}

Although results from laboratory experiments may not always accurately reflect natural-system processes, we think that our results may be relevant to the pelagic environment because: (1) both the substrate concentrations used and nitrification rates observed in this study were generally comparable (same order of magnitude) to the ambient concentrations and rates reported from limnetic environments (Hall 1986); (2) in 2 of the 4 experiments conducted in this study we used the natural assemblage of aquatic organisms rather than cultured organisms; (3) the patterns in trophic control of nitrification were consistent under the different experimental conditions. The major implication of our study is that previously neglected trophic factors may be a potentially important mechanism for mediating aquatic nitrification rates. Given that nitrification presents a significant sink for oxygen (Pakulski et al. 1995, Balls et al. 1996), provides a substrate for denitrification (Seitzinger 1988), and affects other biogeochemical cycles (Vandenabeele et al. 1995), 'top-down' impacts on nitrifying bacteria may potentially have major feedback effects on the ecosystem level. Obtaining direct evidence from natural aquatic systems remains a subject for further research.

A simplified concept (Fig. 5) illustrates direct and indirect trophic interactions that might involve nitrifying bacteria and thus affect the $\mathrm{N}$ cycle in the pelagic zone. Under this scenario, phagotrophic nanoflagel-

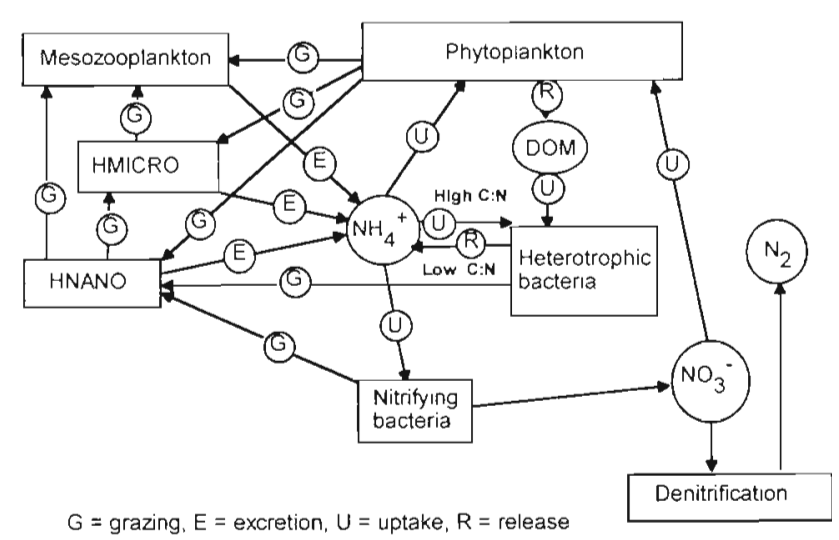

Fig. 5. Simplified conceptual representation of potential interactions between nitrifying bacteria and the microbial food web in the pelagic zone. Denitrification may occur under anoxic conditions in the deeper layers (Seitzinger 1988). Not shown on the figure: zooplankton and ciliate grazing activities also contribute to the labile organic pool (Jumars et al. 1989, Van Wambeke 1995)

lates (or bacterivorous ciliates in hypereutrophic situations) control nitrification directly by reducing bacterial numbers and indirectly by prompting bacterial aggregation. In turn, larger omnivorous ciliates and flagellates diminish grazing control of nitrifiers via predation on bacterivores, while cascading effects of metazooplankton will depend on their composition (i.e. filter-feeders vs raptorial feeders). Nitrifiers growing in aggregates or associated with particles might be also vulnerable to zooplankton filter-feeders as shown for heterotrophic bacteria (Lawrence et al. 1993).

We expect trophic factors to be important in environments characterized by favorable, or at least tolerable, abiotic conditions for nitrification, e.g. transitional zones of estuaries (Feliatra \& Bianchi 1993, Pakulski et al. 1995), reduced-oxygen regions (Ward 1986, Lipschultz et al. 1990), and the primary nitrite maximum (Olson 1981, Ward et al. 1990). In more Nlimited situations, such as oligotrophic areas of the open ocean, the cascading top-down effects on nitrifiers may essentially depend upon the extent of their competition for $\mathrm{NH}_{4}{ }^{+}$with phytoplankton and heterotrophic bacteria (when the $\mathrm{C}: \mathrm{N}$ ratio is high). In other words, we cannot exclude the possibility that under certain circumstances a stimulating effect of bacterivory as $\mathrm{NH}_{4}^{+}$supply for nitrification will exceed its inhibitory effect.

Although this study is concerned with water-column organisms, the pivotal role of protists in consuming heterotrophic bacterial production at the sedimentwater interface and in sediments (e.g. Bott \& Kaplan 1990, Bak et al. 1995) may suggest that similar cascading effects on nitrification are possible in benthic environments. In recent experiments using a flow-through 
system filled with Saginaw Bay sediments, we have found a 3 -fold decrease in the protistan to bacterial $C$ ratio in the overlying water caused by the filter-feeding bivalve Dreissena polymorpha to correspond to a 4 fold increase in nitrification rates (authors' unpubl. data).

\section{Autolithotrophy and the microbial food web: a missing link}

The increasing understanding of microbial interactions based on the numerous studies in different aquatic environments has led to gradual transformation of the original 'microbial loop' concept (Pomeroy 1974, Azam et al. 1983) into the microbial food web (Sherr et al. 1988), which is now spanning from submicron viruses to metazoan invertebrates (Legendre \& Rassoulzadegan 1995). However, chemosynthetic bacteria are not mentioned in any of the above concepts. At the same time, multiple evidence exists for their direct involvement in trophic interactions with different planktonic organisms. Both purple and colorless sulphur bacteria have been repeatedly shown to be grazed by protists (Massana \& Pedros-Alio 1994, Bernard \& Fenchel 1995, Guhl et al. 1996) and metazoan zooplankton (Sorokin 1970, Gophen et al. 1974, Caumette et al. 1983). Microplankton-sized amoeba preyed upon hydrogen- and methane-oxidizing bacteria (Sorokin et al. 1994), whereas acidophilic iron-oxidizers were grazed by Bodo sp. and Cinetochilium sp. (Johnson 1995). Distribution of most autolithotrophs is limited to specific habitats, e.g. the boundary of anoxic/hypoxic zones (Miracle et al. 1992, Sorokin et al. 1995), where their maximums usually coincide with maximum concentrations of protists (Finlay 1983, Zubkov et al. 1992, Fenchel et al. 1995). While trophic interactions between the established components of the microbial food web unanimously play the pivotal role in transferring energy in the pelagic zone, we may hypothesize that, in environments supporting large concentrations of chemosynthetic bacteria, they also can provide the microbial food web with significant quantities of newly-synthesized POM (particulate organic inatter). Morc importantly, combined with a widespread symbiosis between protists and chemosynthetic bacteria (Stumm \& Vogel 1989 and references therein), the almost ubiquitous distribution of protists suggests their inherent involvement in many important biogeochemical processes. As far as we know, no attempt has been made to estimate effects of bacterivory on chemosynthesis rates in the aquatic environment. This concept presents an obvious challenge for both microbial food web and biogeochemical studies.
Acknowledgements. We thank Thomas Johengen for help with $\mathrm{NO}_{3}{ }^{-}$analyses, Irina Lavrentyeva for making microscope preparations, Joann Cavaletto for sharing unpublished data on chlorophyll $a$, David Patterson for suggestions on the protist taxonomy, and the Electron Microscopy Laboratory of the Eastern Michigan University for letting us use SEM. The manuscript benefited from criticisms and discussion provided by Harvey Bootsma, Marie Bundy, James Cotner, Diane Stoecker, Bess Ward, and 3 anonymous reviewers. This study was supported by the Great Lakes Environmental Research Laboratory and by Fulbright grant 18965 to P.L. This is GLERL contribution 971 .

\section{LITERATURE CITED}

Armstrong FAJ, Stearns CR, Strickland JDH (1967) The measurement of upwelling and subsequent biological processes by means of the Technicon AutoAnalyzer and associated equipment. Deep Sea Res 14:381-389

Arrigo KR, Dieckmann G, Gosselin M, Robinson DH, Fristen $\mathrm{CH}$, Sullivan $\mathrm{CW}$ (1995) High resolution study of the platelet ice ecosystem in McMurdo Sound, Antarctica biomass, nutrient, and production profiles within a dense microalgal bloom. Mar Ecol Prog Ser 127:255-268

Azam F, Fenchel T, Field JG, Gray JS, Meyer-Reil LA, Thingstad F (1983) The ecological role of water-column microbes in the sea. Mar Ecol Prog Ser 10:257-263

Bak RPM, van Duyl FC, Nieuwland G (1995) Organic sedimentation and macrofauna as forcing factors in marine benthic nanoflagellate communities. Microb Ecol 29: $173-182$

Balls PW, Brockie N, Dobson J, Johnston W (1996) Dissolved oxygen and nitrification in the upper Forth estuary during summer (1982-92) — patterns and trends. Estuar Coast Shelf Sci 42:117-134

Beaver JR, Crisman TL (1989) The role of ciliated protozoa in pelagic freshwater ecosystems. Microb Ecol 17:111-136

Bergström I, Heinänen $A_{1}$ Salonen K (1986) Comparison of acridine orange, acriflavine, bisbenzimide stains for enumeration of bacteria in clear and humic waters. Appl Environ Microbiol 51:664-667

Bernard C, Fenchel T (1995) Mats of colorless sulphur bacteria. 2. Structure, composition of biota and successional patterns. Mar Ecol Prog Ser 128:171-179

Bernard C, Rassoulzadegan F (1990) Bacteria or microflagellates as a major food source for marine ciliates: possible implications for the microzooplankton. Mar Ecol Prog Ser 64:147-155

Bock E, Koops HP, Harms H (1986) Cell biology of nitrifiers In: Prosser Jl (ed) Nitrification. IRL, Oxford, p 17-38

Bock E, Koops HP, Harms H (1989) Nitrifying bacteria. In Brock TD, Schlegel HG (eds) Autotrophic bacteria. Science Tech, Madison, p 81-96

Bott TI, Kaplan I. (1900) Potential for protozoan grazing of bacteria in streambed sediments. J N Am Benthol Soc 9 $336-345$

Bratbak G (1993) Microscope methods for measuring bacterial biovolume: epifluorescence microscopy, scanning electron microscopy, and transmission electron microscopy. In: Kemp PF, Sherr BF, Sherr EB, Cole JJ (eds) Handbook of methods in aquatic microbial ecology. Lewis, Boca Raton, p 309-317

Bratbak G, Thingstad TF (1985) Phytoplankton-bacteria interactions: an apparent paradox? Analysis of a model system with both competition and commensalism. Mar Ecol Prog Ser 25:23-30 
Burns CW, Schallenberg M (1996) Relative impacts of copepods, cladocerans and nutrients on the microbial food web of a mesotrophic lake. J Plankton Res 18:683-714

Caron DA (1987) Grazing of attached bacteria by heterotrophic microflagellates. Microb Ecol 13:203-218

Caron DA, Goldman JC (1990) Protozoan nutrient regeneration. In: Capriulo GM (ed) Ecology of marine protozoa Oxford University Press, New York, p 283-306

Caron DA, Goldman JC, Dennett MR (1988) Experimental demonstration of the roles of bacteria and bacterivorous protozoa in plankton nutrient cycles. Hydrobiologia 159:27-40

Carrick HJ, Fahnenstiel GL, Stoermer EF, Wetzel RG (1991) The importance of zooplankton-protozoan trophic couplings in Lake Michigan. Limnol Oceanogr 36:1335-1345

Caumette P, Pagano M, Saint-Jean L (1983) Repartition verticale du phytoplancton, des bactéries et du zooplancton dans un milieu stratifié en Baie de Bietri (Lagune Ebrie, Côte d'Ivoire). Relations trophiques. Hydrobiologia 106: $135-148$

Christoffersen K, Riemann B, Hansen LR, Klysner A, Sørensen HB (1990) Qualitative importance of the microbial loop and plankton community structure in a eutrophic lake during a bloom of cyanobacteria. Microb Ecol 20: $253-272$

Chrzanowski TH, Simek K (1990) Prey-size selection by freshwater flagellated protozoa. Limnol Oceanogr 35: 1429-1436

Coveney MF, Wetzel RG (1995) Biomass, production, and specific growth rate of bacterioplankton and coupling to phytoplankton in an oligotrophic lake. Limnol Oceanogr 40:1187-1200

Cox DJ, Bazin MJ, Gull K (1980) Distribution of bacteria in a continuous-flow nitrification column. Soil Biol Biochem 12: $241-246$

Curds CR (1982) The ecology and role of protozoa in aerobic sewage treatment processes. Annu Rev Microbiol 36:27-46

Derange V. Bardin R (1995) Detection and counting of Nitrobacter populations in soil by PCR. Appl Environ Microbiol 61:2093-2098

Elser JJ, Chrzanowski TH, Sterner RW, Schampel JH, Foster DK (1995) Elemental ratios and the uptake and release of nutrients by phytoplankton and bacteria in three lakes of the Canadian Shield. Microb Ecol 29:145-162

Feliatra F, Bianchi M (1993) Rates of nitrification and carbon uptake in the Rhone River plume (Northwestern Mediterranean Sea). Microb Ecol 26:21-28

Fenchel T, Bernard C, Esteban G, Finlay BJ, Hansen PJ, Iversen $N$ (1995) Microbial diversity and activity in a Danish fjord with anoxic deep water. Ophelia 43:45-100

Fenchel T, Blackburn TH (1979) Bacteria and mineral cycling Academic Press, London

Finlay BJ (1983) Nitrate respiration by Protozoa (Loxodes spp.) in the hypolimnetic nitrite maximum of a productive freshwater pond. Freshwater Biol 15:333-346

Gaedke U, Straile D (1994) Seasonal changes of the quantitative importance of protozoans in a large lake. An ecosystem approach using mass-balanced carbon flow diagrams. Mar Microb Food Webs 8:163-188

Gardner WS, Nalepa TF, Malczyk JM (1987) Nitrogen mineralization and denitrification in Lake Michigan sediments. Limnol Oceanogr 32:1226-1238

Gardner WS, St John PA (1991) High-performance liquid chromatographic method to determine ammonium ion and primary amines in seawater. Anal Chem 63:537-540

Gasol JM, Simons AM, Kalff J (1995) Patterns in the top-down versus bottom-up regulation of heterotrophic nanoflagellates in temperate lakes. J Plankton Res 17:1879-1903
Gilbert JJ (1994) Jumping behavior in the oligotrich ciliates Strobilidium velox and Halteria grandiniella, and its significance as a defense against rotifer predators. Microb Ecol 27:189-200

Glover HE (1985) The relationship between inorganic nitrogen oxidation and organic carbon production in batch and chemostat cultures of marine nitrifying bacteria. Arch Microbiol 142:45-50

Gonzalez JM, Sherr EB, Sherr BF (1990) Size-selective grazing on bacteria by natural assemblages of esturaine flagellates and ciliates. Appl Environ Microbiol 56:583-589

Gophen M, Cvari BZ, Berman T (1974) Zooplankton feeding on differentially labelled algae and bacteria. Nature 247: 393-394

Guhl B, Finlay BJ, Schink B (1996) Comparison of ciliate communities in the anoxic hypolimnia of three lakes: general features and the influence of lake characteristics. J Plankton Res 18:335-353

Haga H, Nagata T, Sakamoto M (1995) Size-fractionated $\mathrm{NH}_{4}{ }^{+}$regeneration in the pelagic environments of two mesotrophic lakes. Limnol Oceanogr 40:1091-1099

Hall GH (1986) Nitrification in lakes. In: Prosser JI (ed) Nitrification. IRL, Oxford, p 127-156

Hansen PJ (1991) Dinophrys - a planktonic dinoflagellate genus which can act both as a prey and a predator of a ciljate. Mar Ecol Prog Ser 69:201-204

Hartmann HJ, Taleb H, Aleya L, Lair N (1993) Predation on ciliates by the suspension-feeding calanoid copepod Acanthodiaptomus denticornis. Can J Fish Aquat Sci 50: $1382-1393$

Henriksen K, Kemp WM (1988) Nitrification in estuarine and coastal marine sediments. In: Blackburn $\mathrm{TH}$, Sorensen $\mathrm{J}$ (eds) Nitrogen cycling in coastal marine environments. Wiley \& Sons, Chichester, p 207-240

Henriksen $K$, Blackburn TH, Lomstein BAa, McRoy CP (1993) Rates of nitrification, distribution of nitrifying bacteria, and inorganic $\mathrm{N}$ fluxes in northern Bering-Chukchi shelf sediments. Cont Shelf Res 13:629-651

Hobbie JE, Daley RJ, Jasper S (1977) Use of nucleopore filters for counting bacteria by fluorescence microscopy. Appl Environ Microbiol 33:1225-1228

Jack JD, Gilbert JJ (1993) Susceptibilities of different-sized ciliates to direct suppression by small and large cladocerans. Freshwater Biol 29:19-29

Johnson DB (1995) Acidophilic microbial communities: candidates for bioremediation of acidic mine effluents. Int Biodeter Biodegrad 1:41-58

Jumars PA, Penry DL, Baross JA, Perry MA, Frost BW (1989) Closing the microbial loop: dissolved carbon pathway to heterotrophic bacteria from incomplete ingestion, digestion and absorption in animals. Deep Sea Res 36:483-495

Jürgens K, Güde $H$ (1994) The potential importance of grazing-resistant bacteria in planktonic systems: a review. Mar Ecol Prog Ser 112:169-188

Jürgens K, Arndt H, Rothhaupt KO (1994) Zooplankton-mediated changes of bacterial community. Microb Ecol 27:27-42

Kaplan WA (1983) Nitrification. In: Carpenter EJ, Capone DG (eds) Nitrogen in the marine environment. Academic Press, New York, p 139-190

Kepner RL Jr, Pratt JR (1996) Characterization of surfaceassociated protozoan communities in a Lake Erie coastal wetland (Old Woman Creek, Ohio). J Great Lakes Res 22: 63-76

Kirchman DL, Keil RG, Wheeler PA (1989) The effect of amino acids on ammonium utilization and regeneration by heterotrophic bacteria in the subarctic Pacific. Deep Sea Res 36:1736-1776 
Landry MR, Kirshtein J, Constantinou J (1995) A refined dilution technique for measuring the community grazing impact of microzooplankton, with experimental tests in the central equatorial Pacific. Mar Ecol Prog Ser 120: $53-63$

Lavrentyev PJ, Gardner WS, Cavaletto JF, Beaver JR (1995) Effects of the zebra mussel (Dreissena polymorpha Pallas) on protozoa and phytoplankton in Saginaw Bay, Lake Huron. J Great Lakes Res 21:545-557

Lawrence SG, Ahmad A, Azam F (1993) Fate of particlebound bacteria ingested by Calanus pacificus. Mar Ecol Prog Ser 97:299-307

Lee NM, Welander T (1994) Influence of predators on nitrification in anaerobic biofilm process. Water Sci Tech 29 355-363

Legendre L, Rassoulzadegan F (1995) Plankton and nutrient dynamics in marine waters. Ophelia 41:153-172

Lehman JT (1980) Release and cycling of nutrients between planktonic algae and herbivores. Limnol Oceanogr 25 $620-632$

Lipschultz F, Wofsy SC, Ward BB, Codispoti LA, Friedrich G, Elkins JW (1990) Bacterial transformations of inorganic nitrogen in the oxygen deficient waters of the Eastern Tropical South Pacific Ocean. Deep Sea Res 37:1513-1541

Massana R, Gasol JM, Jürgens K, Pedrós-Alió C (1994) Impact of Daphnia pulex on a metalimnetic microbial community. J Plankton Res 16:1379-1399

Massana R, Pedrós-Alió C (1994) Role of anaerobic ciliates in planktonic food webs - abundance, feeding, and impact on bacteria in the field. Appl Environ Microbiol 60: $1325-1334$

Meyer-Reil LA (1983) Benthic response to sedimentation events during autumn to spring at a shallow water station in the Western Kiel Bight. Mar Biol 77:247-256

Miller CA, Penry DL, Glibert PM (1995) The impact of trophic interactions on rates of nitrogen regeneration and grazing in Chesapeake Bay. Limnol Oceanogr 40:1005-1011

Miracle MR, Vicente E, Pedrós-Alió C (1992) Biological studies of Spanish meromictic and stratified karstic lakes. Limnetica 8:59-77

Nalepa TF, Fahnenstiel GL (eds) (1995) Zebra mussel in the Saginaw Bay, Lake Huron ecosystem. J Great Lakes Res (Spec Issue) 21:411-573

Nation JL (1983) A new method using hexamethyldisilazane for preparation of soft insect tissues for scanning electron microscopy. Stain Tech 58:347-351

Norland S (1993) The relationship between biomass and volume of bacteria. In: Kemp PF, Sherr BF, Sherr EB, Cole JJ (eds) Handbook of methods in aquatic microbial ecology. Lewis, Boca Raton, p 303-307

Olson RJ (1981) ${ }^{15} \mathrm{~N}$ tracer studies of the primary nitrite maximum. J Mar Res 39:203-226

Ooms-Wilms AL, Postema G, Gulati RD (1995) Evaluation of bacterivory of Rotifera based on measurements of in situ ingestion of fiuorescerit paricles, incliuding some comparisons with Cladocera. J Plankton Res 17:1057-1077

Pace ML, Vaqué D (1994) The importance of Daphnia in determining mortality rates of protozoans and rotifers in lakes. Limnol Oceanogr 39:985-996

Pakulski JD, Benner R, Amon R, Eadie B, Whitledge $T$ (1995) Community metabolism and nutrient cycling in the Mississippi River plume: evidence for intense nitrification at intermediate salinities. Mar Ecol Prog Ser 117 : $207-218$

Patterson DJ (1990) Jakoba Libera (Ruinen, 1938), a heterotrophic flagellate from deep oceanic sediments. J Mar Biol Assoc UK 70:381-393
Pomeroy LR (1974) The ocean's food web, a changing paradigm. BioSci 24:499-504

Porter KG, Feig YG (1980) The use of DAPI for identifying and counling aquatic microflora. Limnol Oceanogr 25:943-948

Prosser JI (1986) Experimental and theoretical models of nitrification. In: Prosser JI (ed) Nitrification. IRL, Oxford, p $163-78$

Putt M, Stoecker DK (1989) An experimentaliy determined carbon:volume ratio for marine oligotrichous ciliates from estuarine and coastal waters. Limnol Oceanogr 34: $177-183$

Risgaard-Petersen N, Rysgaard S, Nielsen LP, Revsbech NP (1994) Diurnal variation of denitrification and nitrification in sediments colonized by benthic microphytes. Limnol Oceanogr 39:573-.579

Rittman BE, Regan JM, Stahl DA (1994) Nitrification as a source of soluble organic substrate in biological treatment. Water Sci Tech 130:1-8

Rivkin RB, Legendre L, Debiel D, Tremblay JE, Klein $B$, Crocker K, Roy S, Silverberg N, Lovejoy C, Mesple $F_{\text {, }}$ Romero N, Anderson RM, Matthews P, Savenkoff C, Vezina A, Therriault JC, Wesson J, Berube C, Ingram GR (1996) Vertical flux of biogemic carbon in the ocean: is there food web control? Science 272:1163-1166

Roff JC, Turner JT, Webber MK, Hopcroft RR (1995) Bacterivory by tropical copepod nauplii: extent and possible significance. Aquat Microb Ecol 9:165-175

Rysgaard S, Christensen PB, Nielsen LP (1995) Seasonal variation in nitrification and denitrification in estuarine sediment colonized by benthic microalgae and bioturbating infauna. Mar Ecol Prog Ser 126:111-121

Sanders RW, Leeper DA, King CH, Porter KG (1994) Grazing by rotifers and crustacean zooplankton on nanoplanktonic protists. Hydrobiologia 288:167-181

Sanders RW, Porter KG, Bennett SJ, DeBiase AE (1989) Seasonal patterns of bacterivory by flagellates, ciliates, rotifers, and cladocerans in a freshwater planktonic community. Limnol Oceanogr 34:673-687

Seitzinger SP (1988) Denitrification in freshwater and coastal marine ecosystems: ecological and geochemical significance. Limnol Oceanogr 33:702-724

Selmer JS, Ferrier-Pages C, Cellario C, Rassoulzadegan F (1993) New and regenerated production in relation to the microbial loop in the NW Mediterranean Sea. Mar Ecol Prog Ser 100:71-83

Sherr BF, Sherr EB, Hopkinson CS (1988) Trophic interactions within pelagic microbial communities: indications of feedback regulation of carbon flow. Hydrobiologia 159 $19-26$

Sherr EB, Rassoulzadegan F, Sherr BF (1989) Bacterivory by pelagic choreotrichous ciliates in coastal waters of the NW Mediterranean Sea. Mar Ecol Prog Ser 55:235-240

Sherr EB, Sherr BF (1993) Protistan grazing rates via uptake of fluorescently labeled prey. In: Kemp PF, Sherr BF, Sherr $E B$, Cole IJ (eds) Handhook of methods in aquatic microbial ecology. Lewis, Boca Raton, p 695-701

Sibbald MJ, Albright LJ (1988) Aggregated and free bacteria as food source for heterotrophic flagellates. Appl Environ Microbiol 54:613-616

Simek K, Vrba J, Lavrentyev PJ (1994) Estimates of protozoan bacterivory: from microscopy to ectoenzyme assay? Mar Microb Food Webs 8:71-85

Sommaruga R, Psenner R (1995) Trophic interactions within the microbial food web in Piburger-See (Austria). Arch Hydrobiol 132:257-278

Sorokin YI (1970) Interaction between sulphur and carbon turnover in meromictic lakes. Arch Hydrobiol 66:391-446 
Sorokin YI, Sorokin PY, Avdeev VA, Sorokin DY, Ilchenko SV (1995) Biomass, production and activity of bacteria in the Black Sea, with special reference to chemosynthesis and the sulfur cycle. Hydrobiologia 308:61-76

Sorokin YI, Sorokin PY, Zakuskina OY (1994) Microplankton and its functional activity in the by-shore hydrothermal areas in the western Pacific. Zh Obshch Biol 55:30-48 (in Russian)

Stumm CK, Vogel GD (1989) Autotrophic bacteria in protozoa. In: Brock TD, Schlegel HG (eds) Autotrophic bacteria. Science Tech, Madison, p 177-191

Suzuki M, Sherr EB, Sherr BF (1996) Estimation of ammonium regeneration efficiencies associated with bacterivory in pelagic food webs via a ${ }^{15} \mathrm{~N}$ tracer method. J Plankton Res 18:411-428

Vandenabeele J, Vande Woestyne VM, Houwen F, Germonpre R, Vandesande D, Verstraete W (1995) Role of autotrophic nitrifiers in biological manganese removal from groundwater ontaining manganese and ammonium. Microb Ecol 29:83-98

Vanderploeg HA (1994) Zooplankton particle selection and feeding mechanisms. In: Wotton RS (ed) The biology of particles in aquatic systems. Lewis, Boca Raton, p 205-234

Van Wambeke F (1995) Fate of Phaeodactylum tricornutum and nitrogen flow in an experimental microbial food web limited at the top by protozoans. Aquat Microb Ecol 9: $127-136$

Van Wambeke F, Bianchi MA (1985) Bacterial biomass production and ammonium regeneration in Mediterranean sea water supplemented with amino acids. 2. Nitrogen flux through heterotrophic microplankton food chain. Mar Ecol Prog Ser 23:117-128

Vaqué D, Pace ML, Findlay S, Lints D (1992) Fate of bacterial production in a heterotrophic ecosystem: grazing by protists and metazoans in the Hudson Estuary. Mar Ecol Prog Ser 89:155-163

Responsible Subject Editor: Faroog Azam, La Jolla, California, USA
Verhagen FJM, Laanbroek HJ (1992) Effects of grazing by flagellates on competition for ammonium between nitrifying and heterotrophic bacteria in chemostats. Appl Environ Microbiol 58:1962-1969

Verity P (1991) Measurement and stimulation of prey uptake by marine planktonic ciliates fed plastidic and aplastidic nanoplankton. Limnol Oceanogr 36:729-750

Voytek MA, Ward BB (1995) Detection of ammonium-oxidizing bacteria of the betasubclass of the class Proteobacteria in aquatic samples with the PCR. Appl Environ Microbiol 61:1444-1450

Ward BB (1986) Nitrification in marine environment. In Prosser JI (ed) Nitrification. IRL, Oxford, p 157-184

Ward BB, Kilpatrick KA, Renger EH, Eppley RW (1990) Biological nitrogen cycling in the nitracline. Limnol Oceanogr $34: 493-513$

Wiackowski K, Brett MT, Goldman CR (1994) Differential effects of zooplankton species on ciliate community structure. Limnol Oceanogr 39:486-492

Winogradsky S (1890) Recherches sur les organismes de la nitrification. Ann Inst Pasteur 4:213-331

Woese CR, Stackebrant E, Weisburg WG, Paster BJ, Madigan MT, Flower VJ, Hahn CM, Blanz P, Gupta R, Nealson KH, Fox GE (1984a) The phylogeny of purple bacteria: the alpha subdivision. Syst Appl Microbiol 5: 315-326

Woese CR, Weisburg WG, Paster BJ, Hahn CM, Tanner RS Krieg NR, Koops HP, Harms H, Stackebrandt E (1984b) The phylogeny of purple bacteria: the beta subdivision. Syst Appl Microbiol 5:327-336

Wood PM (1986) Nitrification as a bacterial energy source. In Prosser JI (ed) Nitrification. IRL, Oxford, p 39-62

Yoshioka T, Sajo Y (1984) Photoinhibition and recovery of $\mathrm{NH}_{4}{ }^{+}$-oxidizing bacteria and $\mathrm{NO}_{2}^{-}$-oxidizing bacteria J Gen Appl Microbiol 30:151-166

Zubkov MV, Sazhin AF, Flint MV (1992) The microplankton organisms at the oxic-anoxic interface in the pelagial of the Black Sea. FEMS Microbiol Ecol 101:245-250

Manuscript received: September 15, 1996

Revised version accepted: March 6, 1997 